\title{
CEPHALIC INDICES OF SOME BIRDS IN RELATION TO THEIR FEEDING HABITS
}

\author{
Pramod Kumar Kushwaha \\ Department of Zoology
}

\begin{abstract}
The shape and size of skull and arrangement of mouth parts play an important role to determine the food and feeding behavior of birds. The cephalic or head index is a ratio between breadth and length of head. The numerical procedure of cephalic indices of birds represent an important taxonomic character and also help to establish the relationship of feeding habits to visual and acoustic organs of birds. Birds have evolved a great variety of beaks according to their food habits. Due to different food habits found in birds, they possess various types of beaks of special structure. This article deals with cephalic indices of some birds of Uttar Pardesh (India) in relation to their feeding habits.
\end{abstract}

\section{Keywords}

Skull, bill, measurement, ratio, relation

\section{Introduction}

The arrangement of bones of skull play an important role in food habits of the birds. The slender and elongated bone of jaws of a bird is an important character. The upper jaw consists of an enlarged triradiate premaxillae and maxillae bones while the lower jaw and mandible are a complex bones. The opening between both jaws is increased by quadrate bone which helps in swallowing the food without chewing. The shortening and lengthening of bills depend upon the length of premaxillae. The bill of a particular bird is characteristic modified according to its food habits.

Skull index (S.I) is obtained by dividing the breadth of the skull by length of the skull. It has observed that the birds with skull indices possess longer bills in length, while the birds with higher skull indices posses shorter bill in length but in certain cases it may be moderately long. The birds having greater cephalic indices seem to be more intelligent due to their well-developed brain, 


\section{P.K Kushwaha}

sense organs (visual and acoustic) and they have wide skulls that provide broad base for attachment of adductor muscles which help in feeding and in tight gripping of their food material. Among studied birds Athene brama had greater skull index (0.75mm) while Upupa epops had lowest skull index (0.20mm).

Twenty birds with different feeding habits were examined to determined the cephalic indices. These are as follows:

Psittacula krameri (Rose ringed Parakeet)

Milvus migrans (Common Pariah Kite)

Haliastur indus (Brahminy Kite)

Anas poecilorhyncha (Spotbill or Grey duck)

Anser indicus (Bar-headed Goose)

Bublucus ibis (Cattle Egret)

Athene brama (Spotted Owlet)

Tyto alba (Barn Owl)

Upupa epops (Hoopoe)

Alcedo atthis (Small blue Kingfisher)

Gallus gallus (Red Jungle Fowl)

Francolinus pondicerianus (Grey Partridge)

Columba livia (Blue rock Pigeon)

Streptopelia decaocto (Ring Dove)

Acridotheres tristis (Common Myna)

Passser domesticus (House Sparrow)

Ploceus philippinus (Baya Weaver Bird)

Acridotheres ginginianus (Bank Myna)

Corvus splendens (House Crow)

Corvus macrorhynchos (Jungle Crow)

\section{Materials and methods}

Twenty birds were examined to determine cephalic index. The measurements of the species were recorded irrespective of the sex of the individual birds as the structural proportion of male and female birds was found to be similar. For the collection of the material, birds were shot with catapult and marbles, also used slingshot. Help of bird catcher was also availed. The head was separated and preserved in $10 \%$ formalin for 48 hours. After washing the preserved heads with tap water, the muscles were removed with a pair of fine scissors as completely as possible. Five percent $\mathrm{KOH}$ solution was used for a few days to remove the remaining muscles. Skulls were constantly observed so that the cranial elements did not disarticulate. After removing the alkaline solution, skull were thoroughly washed with water, then bleached with hydrogen peroxide, cleared in $50 \%$ glycerin and dried in an oven at $40^{\circ} \mathrm{C}$. A caliper (accuracy of $1.00,0.05 \mathrm{~mm}$ ) and a measuring rod accuracy of $(1.00,0.25 \mathrm{~mm})$ were used to measure skull lengths and cranial lengths as well as their breadth. Skull index (S.I) was obtained by dividing the breadth of the skull by length of the skull. For obtaining the cranial index (C.I) the cranial breadth was divided by cranial length (C.L.). The following dimension for obtaining the skull and cranial indices were recorded in $\mathrm{mm}$ (Table 1 )

Skull Length: It is distance between lamboidal crest and anterior tip of the bill.

Skull or Cranial breadth: It is the widest distance of skull or cranium i.e. the distance between the lateral surface of distal ends of post-orbital process.

Cranial Length: It is the distance between the fronto-nasal hinge and lamboidal crest.

Bill Length: It is the distance between the anterior tip of upper jaw and frontonasal hinge

Skull length: Cranial length + bill length

Cranial Length: Skull Length - bill length

\section{Observations and results}

It has been observed that birds with lower skull indices possess longer bills in length, while the birds with higher skull indices possess shorter bill in length but in certain cases it may be moderately long as in Corvus splendens and Corvus macrorhynchos, they have slightly greater skull indices. The birds having greater cranial indices seem to be 
Table 1 : Measurement of skull components (in $\mathbf{m m}$ )

\begin{tabular}{|c|c|c|c|c|c|c|c|c|c|}
\hline \multirow[t]{2}{*}{ Name of Birds } & \multirow{2}{*}{$\begin{array}{c}\text { No. } \\
\text { of } \\
\text { Birds }\end{array}$} & \multicolumn{2}{|c|}{ Skull length } & \multicolumn{2}{|c|}{ Crenial breadth } & \multicolumn{2}{|c|}{ Cranial length } & \multicolumn{2}{|c|}{ Bill Length } \\
\hline & & Range & Mean & Range & Mean & Range & Mean & Range & Mean \\
\hline Psittacula krameri & 10 & $42.5-46.5$ & 44.50 & $24.5-26.5$ & $25 \cdot 50$ & $28.5-31.5$ & 30.0 & $14.0-15.0$ & 14.50 \\
\hline Milvus migrans & 4 & $76.0-82.0$ & 78.25 & $39.0-43.0$ & 41.0 & $46.5-48.0$ & 47.25 & $30.5-33.5$ & 32.0 \\
\hline Haliester indus & 5 & $77.0-82.0$ & 79.0 & $41.0-43.0$ & 42.0 & $47.0-48.0$ & $47 \cdot 42$ & $32.5-34.0$ & 33.18 \\
\hline Anes poicilorhyncha & 7 & $88.0-91.5$ & 89.7 & $23.0-26.5$ & 23.75 & $41 \cdot 5-45 \cdot 5$ & 43.72 & $38.5-42.0$ & 40.14 \\
\hline Anser indicus & 6 & 88.0-91.0 & 89.42 & $28.5-31.5$ & 30.03 & $3 \cdot 6.0-38.0$ & 37.0 & 51.0-53.0 & 52.03 \\
\hline Bubulcus ibis & 6 & $\begin{array}{l}96.0- \\
100.5\end{array}$ & 98.42 & $23 \cdot 5-25.0$ & 24.2 & $37 \cdot 5-41.0$ & 39.25 & $52.5-55 \cdot 5$ & 53.88 \\
\hline Athene brama & 5 & $43 \cdot 5-46.5$ & 45.0 & $33 \cdot 0-34 \cdot 5$ & 33.75 & $29 \cdot 5-31.5$ & 30.50 & $14.0-15.0$ & 14.50 \\
\hline Tyto alba & 5 & $43.0-46.0$ & $44 \cdot 36$ & $28.0-31.0$ & 29.50 & $28.5-32.0$ & 29.78 & $14.5-15.0$ & 14.88 \\
\hline Upapa epops & 4 & $81.5-81.0$ & 82.72 & $15 \cdot 5-17 \cdot 0$ & 16.25 & $23 \cdot 5-25 \cdot 0$ & 24.25 & $\begin{array}{l}50.0- \\
54.0\end{array}$ & 52.33 \\
\hline Alcedo attis & 5 & $50.0-54.0$ & 52.18 & $19.0-21.0$ & 20.0 & $28.0-31.5$ & 29.8 & $51.0-52.5$ & 51.88 \\
\hline Gallus gallus & 8 & $72.0-75 \cdot 5$ & 73.8 & $27.0-31.5$ & 29.25 & $36.5-40.5$ & 38.50 & $30.5-33.0$ & 31.90 \\
\hline $\begin{array}{l}\text { Froncolinus } \\
\text { pondicerianas }\end{array}$ & 5 & $70.0-71.5$ & 70.75 & $30.0-32.0$ & 31.18 & $51.5-52.0$ & 51.75 & $18.5-19.5$ & 19.0 \\
\hline Columba livia & 10 & $51.0-55 \cdot 5$ & 53.25 & $21.0-22.5$ & 21.25 & $29.0-32.0$ & 30.50 & $22.0-23.5$ & 21.75 \\
\hline $\begin{array}{l}\text { Streptopelia } \\
\text { docaocto }\end{array}$ & 6 & $49 \cdot 5-54 \cdot 5$ & 52.0 & $21.0-21.5$ & 20.75 & $28.5-31.5$ & 30.0 & $21.0-23.0$ & 22.0 \\
\hline Acridothres tristis & 8 & $51.0-52.0$ & 51.50 & $19.0-20.0$ & $19 \cdot 50$ & $26.5-27.5$ & 27.0 & $24 \cdot 5-25 \cdot 5$ & 25.0 \\
\hline Passer domesticus & 10 & $28.0-31.5$ & $29 \cdot 75$ & $14.0-15.0$ & $14 \cdot 50$ & $17.0-18.5$ & 17.75 & $11.0-13.0$ & 12.0 \\
\hline Ploceous philippinus & 6 & $27.0-30.5$ & 28.25 & $13.0-14.0$ & 13.48 & $16.5-18.0$ & 17.11 & $11.5^{-12.5}$ & 12.03 \\
\hline $\begin{array}{l}\text { Acridotheres } \\
\text { ginginianus }\end{array}$ & 8 & $50.0-53 \cdot 5$ & 51.85 & $18.0-20.0$ & 18.93 & $26.0-27.5$ & 26.68 & $24 \cdot 5-25 \cdot 5$ & 24.93 \\
\hline Corpus splendens & 10 & $78.5-82.0$ & 80.25 & $32 \cdot 5-33 \cdot 5$ & 33.0 & $34.5-36.0$ & 35.25 & $\begin{array}{l}45.0- \\
46.0 \\
\end{array}$ & $45 \cdot 50$ \\
\hline $\begin{array}{l}\text { Corpus } \\
\text { macrorhynchos }\end{array}$ & 8 & $79.0-84.0$ & 81.51 & $33 \cdot 0-34 \cdot 5$ & $33 \cdot 77$ & $34.5-36.5$ & 35.27 & $44.5-46.5$ & 45.85 \\
\hline
\end{tabular}

Skull Length: It is distance between lamboidal crest and anterior tip of the bill.

Skull or Cranial breadth: It is the widest distance of skull or cranium i.e. the distance between the lateral surface of distal ends of post-orbital process.

Cranial Length: It is the distance between the fronto-nasal hinge and lamboidal crest.

Bill Length: It is the distance between the anterior tip of upper jaw and frontonasal hinge

Skull length: Cranial length + bill length

Cranial Length: Skull Length - bill length 
move intelligent due to their well-developed brain, sense organs and they have wide skulls that provide broad base for attachment of abductor muscles, which help in feeding and in tight gripping of their food material. Among the studied birds Athene brama(0.75mm) skull index, followed by Tyto alba(0.66mm) Psittacula krameri (0.57mm), Haliastus indus (o.53mm) Milvus migrans (0.51mm) have short bills. Corvus macrorhynchos and Corvus splendens have moderately long bill which have small differences in their skull indices i.e. $(0.42 \mathrm{~mm})$ and $(0.41 \mathrm{~mm})$ respectively. Upaps epops (o.20mm) has lowest skull index, Bulbulcus ibis and Anas poecilorhyncha have $(0.24 \mathrm{~mm})$ and $(0.28 \mathrm{~mm})$ respectively. The average bill lengths of Upapa epops, Bubulcus ibis and Anas poecilorhyncha are $(52.13 \mathrm{~mm})$ and $(40.14 \mathrm{~mm})$ respectively. In relation to body weight and size Upupa epops has the longest bill. The bills of Bubulcus ibis and Anas poecilorhyncha are shorter in size. A persual of skull indices in Table 2 will suggest that skull with lower indices have longer bills and skull

Table 2 : Skull indices of studied birds

\begin{tabular}{|c|c|c|}
\hline Name of Birds & Range & Mean \\
\hline Athene brama & $0.74-0.76$ & 0.75 \\
\hline Tyto alaba & $0.65-0.67$ & 0.66 \\
\hline Psittacula krameri & $0.57-0.5^{8}$ & 0.56 \\
\hline Haliastar indus & $0.52-0.53$ & 0.52 \\
\hline Milves migrans & $0.5^{1-0.52}$ & 0.51 \\
\hline Passer domesticus & $0.47-0.50$ & 0.49 \\
\hline Ploceous philippinus & $0.46-0.48$ & 0.47 \\
\hline Francolinus pondicerianus & $0.43-0.45$ & 0.44 \\
\hline Carvus macrorynchos & $0.41-0.42$ & 0.42 \\
\hline Corvus splendens & $0.10-0.41$ & 0.41 \\
\hline Columba livia & $0.40-0.41$ & 0.41 \\
\hline Streptopelia decaocto & $0.39-0.40$ & 0.40 \\
\hline Gallus gallus & $0.38-0.41$ & 0.40 \\
\hline Alcido althis & $0.38-0.39$ & 0.39 \\
\hline Acridotheres tristis & $0.37-0.38$ & 0.38 \\
\hline Acridotheris ginginianus & $0.36-0.37$ & 0.37 \\
\hline Anser indicus & $0.32-0.35$ & 0.34 \\
\hline Anas poecilorhyncha & $0.26-0.29$ & 0.28 \\
\hline Bubulcus ibis & $0.24-0.25$ & 0.25 \\
\hline Upapa ероs & $0.19-0.20$ & 0.20 \\
\hline
\end{tabular}

with higher skull indices have shorter bills in relation to their body weight and size.

The cranial indices of the studied birds given in Table 3 show that Athene brama (1.11mm) has the highest cranial index and widest skull. Birds with higher cranial indices such as Tyto alba (0.98mm), Corrus macrorhynchos (0.95mm), Corvous splendens (0.94mm) etc. have greater intelligence than birds with lower cranial indices such as Bubulcus ibis (0.62 $\mathrm{mm})$, Francolinus pondicerianus (o.6omm) and Anas poecilorhyncha $(0.57 \mathrm{~mm})$. Birds with higher cranial indices may have developed brains and sense organs than other with lower cranial indices.

In the studied birds, correlation coefficient between cranial index and bill length have been observed (Table 4). According to correlation coefficient between cranial index and bill length, it has been observed that cranial index and bill length are negatively $(-0.26 \mathrm{~mm})$ related to each other. If the bill length is increased, the sense organ, intelligence and

Table 3 : Cranial indices of studied birds

\begin{tabular}{|l|c|c|}
\hline \multicolumn{1}{|c|}{ Name of Birds } & Range & Mean \\
\hline Athene brama & $1.10-1.12$ & 1.11 \\
\hline Tuto alaba & $0.97-0.98$ & 0.98 \\
\hline Corvus macrorhynchos & $0.94-0.95$ & 0.95 \\
\hline Corvus splendens & $0.93-0.94$ & 0.94 \\
\hline Milves migrans & $0.84-0.89$ & 0.87 \\
\hline Haliastus indus & $0.86-0.87$ & 0.87 \\
\hline Psittacula krameri & $0.84-0.86$ & 0.85 \\
\hline Passer domesticus & $0.81-0.82$ & 0.82 \\
\hline Anser indicus & $0.79-0.83$ & 0.81 \\
\hline Ploceus phillipinus & $0.77-0.78$ & 0.78 \\
\hline Gallus gallus & $0.74-0.77$ & 0.76 \\
\hline Acridotheres tristis & $0.71-0.72$ & 0.72 \\
\hline Aeridotheres ginginianus & $0.70-0.72$ & 0.71 \\
\hline Columba livis & $0.70-0.72$ & 0.71 \\
\hline Upupa epos & $0.66-0.72$ & 0.69 \\
\hline Streptopelia decaocto & $0.68-0.70$ & 0.69 \\
\hline Alcido atthis & $0.66-0.72$ & 0.67 \\
\hline Bubulcus ibis & $0.61-0.63$ & 0.62 \\
\hline Francolinuspondicerinus & $0.58-0.62$ & 0.60 \\
\hline Anas poeccilorhyncha & $0.55^{-0.58}$ & 0.57 \\
\hline
\end{tabular}


grip over the food is automatically decreased.

\section{Discussion}

Cephalic index of the bird is related to their feeding habits, type of diet, length of bill and muscles are responsible for its movement, intelligence and their sense organs, especially the organs of sight and sound. Beak, the food handling machinery and its correlation with is obvious as its main duty is to expose,

Table 4 : Measurement of relationship between cranial index and bill length. Let the cranial index be $X$ and bill length be $Y$

\begin{tabular}{|c|c|c|c|c|c|}
\hline Name of birds & $\begin{array}{c}\text { Cranial } \\
\text { index }(\mathrm{X})\end{array}$ & $\begin{array}{c}\text { Bill } \\
\text { Length }(\mathrm{Y})\end{array}$ & $\mathrm{X}^{2}$ & $\mathrm{Y}^{2}$ & $\mathrm{XY}$ \\
\hline Athene brama & 1.11 & 14.50 & 1.23 & 210.25 & 16.10 \\
\hline Tyto alba & 0.98 & 14.88 & 0.96 & 221.41 & 14.58 \\
\hline Corvus macrorhyncos & 0.95 & 45.85 & 0.90 & 2102.22 & $43 \cdot 56$ \\
\hline Corvus splendens & 0.94 & $45 \cdot 50$ & 0.88 & 2070.25 & 42.77 \\
\hline Milves migrans & 0.87 & 32.00 & 0.76 & 1024.00 & 27.84 \\
\hline Haliastur indus & 0.87 & 33.18 & 0.76 & 1100.91 & 28.87 \\
\hline Psittacula krameri & 0.85 & 14.50 & 0.72 & 210.25 & 12.33 \\
\hline Passer domesticus & 0.82 & 12.0 & 0.67 & 144.00 & 9.84 \\
\hline Anser indicus & 0.81 & 52.03 & 0.66 & 2707.12 & 42.14 \\
\hline Ploceus philippinus & 0.78 & 31.90 & 0.61 & 1017.61 & 24.88 \\
\hline Gallus gallus & 0.76 & 25.00 & 0.58 & 625.00 & 19.00 \\
\hline Acridotheres tristis & 0.72 & 25.00 & 0.52 & 625.00 & 18.00 \\
\hline $\begin{array}{l}\text { Acrid otheres } \\
\text { ginginianus }\end{array}$ & 0.71 & 24.93 & 0.50 & 621.50 & 17.70 \\
\hline Columba livia & 0.71 & 21.45 & 0.50 & 473.06 & 15.44 \\
\hline Upapa ерорs & 0.69 & 52.13 & 0.48 & $2717 \cdot 54$ & $35 \cdot 97$ \\
\hline Streptopelia decaocto & 0.69 & 22.00 & 0.48 & 484.00 & 15.18 \\
\hline Alcida atthis & 0.67 & 51.88 & 0.45 & 2691.53 & $34 \cdot 76$ \\
\hline Bubulcus ibis & 0.62 & 53.88 & 0.38 & 2903.05 & 33.41 \\
\hline 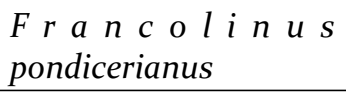 & 0.60 & 19.00 & 0.36 & 361.00 & 11.40 \\
\hline Anas poecilorhyncha & 0.57 & 14.14 & 0.32 & $199 \cdot 94$ & 16.10 \\
\hline Total & $\sum X=15 \cdot 72$ & $\sum Y=619.08$ & $\sum X^{2}=12.71$ & $\sum \mathrm{Y}^{2}=234953$ & $\sum X Y=476.38$ \\
\hline \multicolumn{3}{|c|}{$=\frac{20 \times 476.38-15.72 \times 619.08}{5}$} & \multicolumn{2}{|c|}{$=\frac{-204.34}{2.66 \times 294.3}$} & \\
\hline \multicolumn{3}{|c|}{$\sqrt{20 \times 12.71-(15.72)^{2} x} \sqrt{20 \times 23493-(619.08)^{2}}$} & $=\frac{-204.34}{782.84}$ & \multirow{2}{*}{\multicolumn{2}{|c|}{$\begin{array}{l}r=\text { Karl Pearson co-efficient } \\
n=\text { Number of Observations }\end{array}$}} \\
\hline \multicolumn{3}{|c|}{$\begin{array}{l}=\frac{9527.6-9731.94}{\sqrt{254.2-247.12 x} \sqrt{469870.6-383260.04}} \\
=\frac{-204.34}{\sqrt{708} \times \sqrt{8661056}}\end{array}$} & $\begin{array}{l}=-0.26 \\
\text { Here, }\end{array}$ & & \\
\hline
\end{tabular}


seize and if necessary kill as well as prepare food for swallowing. The carnivorous birds are of two types, diurnal predator eagles, falcons, hawks and nocturnal predator owls. They have strong hooked and sharp powerful talons that are used in grasping prey. Owls have no crop and they swallow prey as whole and digest meat, bone, fur, feathers and cost of indigestible residue in several pellets while vultures take small prey as their feet are weak (Welty, 1964). Forelimbs of birds are modified as organs for flight and therefore, can be used in grasping and holding food materials. Hence the bill and upto some extent hind limbs take over the grasping and holding function. Owl and parakeet are exceptional in that their feet may be used as hand to lift to mouth beak. Food habits of different birds are described by Ali(1977). The bill of a bird is a potent weapon as it can be used for defense purposes. Van Tyne (1929) has suggested that longer bills help in reaching the birds upto their food at the time of feeding. Due to short bill length of Athene brama the gap is narrow, which helps in removing a part of prey body before swallowing and also increases ability during beheading operations of the prey. The bird Upupa epops with its long bill thrusts into soil very easily for food. Corvus splendens does not require chiseling and sheering operations, it can feed and swallow grains as whole. The long bill of Bubulcus ibis is advantageous, as it can feed on relatively larger insects. According to Young (1973), the carnivorous birds such as owl and eagles have short bills, while fish consuming birds and herons have long bill, songthrush with moderately long bill can eat either flesh or fruit.

The birds with much higher indices have short and sharp bill, such as the carnivorous birds. Athene brama, Tyto alba, Haliastur indus and Milvus migrans. Psittacula krameri, a frugivorous birds feed on ripe and semiripe fruits causing much damage thus reducing our yield (Kushwaha and Kumar , 2007). Psittacula krameri has a special type of operational arrangement in which there is a hinge between beak and skull that enables mastication movements of a unique characters. The seed eating birds Acridotheres tristis, Ploceus philippinus and Passer domesticus possess short bills. Birds with slightly higher indices have moderately long bills eg. Corvus macrorhynchos and Corvus splendens, whose bills are adopted for feeding upon seeds, fruits and flesh. Therefore this bird does not die due to scarcity of food as it ingests other food material (Kumar, 1989). The insect eating birds Upupa epops and Bubulcus ibis have lower skull index and long bills. The bills of these birds are adapter for than own type of food.

Generally the bills of lower skull indices or long bills have no forces on their tips because there is reduction on effective force, while bills of greater skull indices can hold the food effectively, it can be expressed in other words, the long bills are unable to pick the food from the ground (Zusi 1962), shorter bills provides effective force to hold the prey firmly. Shorter bills are found in grasping Anatids (Goodman and Fisher, 1962) but fish eating Anatids have longer bills. Goldfinches (Carduelis) with small bills feed on birds and small seeds while Howfinch (Coocothraustes) with large bills feed on cherries or olives by cracking their stones and exert a force of $\mathrm{Ca} 45 \mathrm{Kg}$ (Sims, 1955)

The birds are eye brained animals as many fishes are nose brained. Among 20 studied birds Athene brama has the highest cranial index $(1.11 \mathrm{~mm})$ and the widest skull. The wide skull provides a broad base for the attachment of muscles, which help in feeding cranial length of Athene brama is lower than cranial breadth, which suggest a tight grip over the food. As the wideness of the skull decreases in relation to cranial length the tightness of the food decreases. The brain is well developed and fills the entire cranial cavity. The eyes are well developed and very large. The acoustic organ with distinct slightly curved cochlea is present. All these are due to its greater cranial index. Predatory birds have

keen eye sight, only the nocturnal predatory birds have highly developed hearing organ, 
which help in locating their prey in night. An owl finds its prey largely with the help of its ear (Welty, 1964)

The highest cranial index (1.11mm) of Athene brama is followed by Tyto alba (0.98mm), Corvus macrorhynchos (0.95mm), Corvus splendens $(0.94 \mathrm{~mm})$ Milves migrans (o.87mm) suggesting their higher intelligence. Psittacula kerameri with a distinct slightly curved cochlea in the internal ear can imitate the simple tunes. Bubulcus ibis (o.6omm) seems to be lesser intelligent due to smaller brain. The gripping power over their food is not powerful, as they possess less wide skulls. The forebrain is large especially in crows and parrots and their behaviours show sign of outstanding intelligence as the finer sense is restricted to the eyes, ears and bills (Young, 1973). In present observation, they show higher skull and cranial indices.

The correlation coefficient ( $\mathrm{r}$ ) of studied birds show that there is negative(-) or low degree correlation $(0.279 \mathrm{~mm})$ between cranial index and bill length of different birds such as the cranial indices (1.11mm), (0.98mm), (0.95mm) and $(0.94 \mathrm{~mm})$ of Athene brama, Tyto alba, Carvus macrorhynchos and Corvus splendens have bill lengths $(14.5 \mathrm{Omm}) \quad(14.88 \mathrm{~mm})$ $(45.85 \mathrm{~mm})$ and $(45.50 \mathrm{~mm})$ respectively. Hence, larger cranial index has relatively small bill length and vice-versa.

\section{Acknowledgement}

The author expresses his sincere thanks to Prof. Dr. Prabhat Kumar, Department of
Zoology, Lucknow University, Uttar pradesah, India for his keen interest in this work and also for providing necessary laboratory facilities in the Department.

\section{References}

Ali, S. (1977). The role of birds in agriculture and forestry. Tiger Paper, 14, 1-3.

Goodman, D.C. and Fisher, H.I. (1962). Functional anatomy of the feeding apparatus in water fowl (Anatidae). Illinois: Southern Illinois University Press.

Kumar, P. (1989). Role of birds in management of Crops. Bulletin of Entomology, 30, 148 - 152.

Kushwaha, P. and Kumar, P. (2007). Ecology of Psittacula Krameri, Scopoli, A frugivorous birds with special reference to its role as a pest of crop and fruits. Lucknow Journal of Science 4, 47-57.

Sims,R.W. (1955). The morphology of the head of the Howfinch (Coccothraustes coccothrauses). Bulletin of British Museum (Natural History). 2, 371-393.

Van Tyne, J. (1929) . The life history of toncan (Ramphastos brevicarenatus). University of Michigan Museum of Zoological Miscellaneous Publication. 19, 1- 43.

Welty, J.C. (1964). The life of birds. London: W.B.Saunders company.

Young, J.Z.(1973). The life of vertebrates. London: Oxford University Press.

Zusi, R.L.(1962). Structure adaptations of the head and neck in the black skimmer. Nuttas Ornithological Club. ......

\section{The Author}

Pramod Kumar Kushwaha is an Associate Professor in Zoology in Thakur Ram Multiple Campus, Birgunj. He has been involved in teaching Bird Ecology and Biodiversity Management in the campus for more than two decades. He obtained Ph.D. in Zoology from University of Lucknow, India. To his credit, he has widely published in journals. 